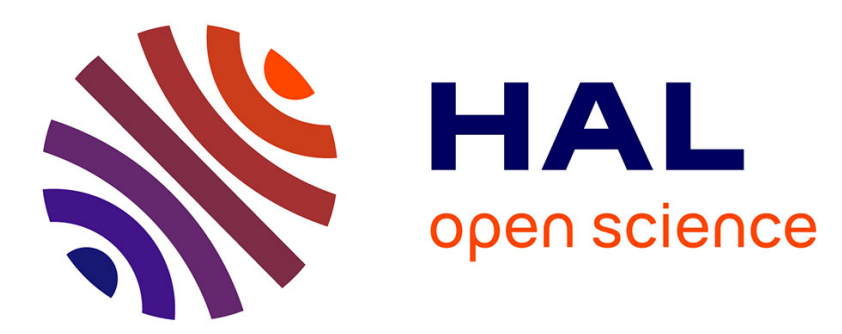

\title{
Economists' Controversies about the Causality between War and Economic Cycles
}

Fanny Coulomb, Liliane Bensahel, Jacques Fontanel

\section{To cite this version:}

Fanny Coulomb, Liliane Bensahel, Jacques Fontanel. Economists' Controversies about the Causality between War and Economic Cycles. Manas Chatterji; Chen Bo; Rameshwar Misra. Frontiers of Peace Economics and Peace Science, 16, Emerald Group Publishing Limited, pp.85-97, 2011, Contributions to Conflict Management, peace economics and dévelopment, 978-0-85724-701-8. hal-01989057

\section{HAL Id: hal-01989057 \\ https://hal.univ-grenoble-alpes.fr/hal-01989057}

Submitted on 12 Feb 2019

HAL is a multi-disciplinary open access archive for the deposit and dissemination of scientific research documents, whether they are published or not. The documents may come from teaching and research institutions in France or abroad, or from public or private research centers.
L'archive ouverte pluridisciplinaire HAL, est destinée au dépôt et à la diffusion de documents scientifiques de niveau recherche, publiés ou non, émanant des établissements d'enseignement et de recherche français ou étrangers, des laboratoires publics ou privés. 
Fanny Coulomb, Liliane Bensahel, Jacques Fontanel, Economists' controversies about the causality between war and economic cycles. Frontiers of peace economics and peace science, Editors Chatterji, M., Chen Bo, Missra, R. Contributions to Conflict Management, peace economics and dévelopment, Vol. 16, Emerald, 2011.

The issue of the link between wars and economic cycles and of the sense of the causality has given rise to many economic studies. The statistical works of N.D. Kondratiev ${ }^{1}$ in the 1930s, showing the existence of long economic cycles regulating capitalism, have much contributed to the economic cycles' theory. This analysis based on the observation of long-term economic changes in GDP growth rates and/or price levels, allows showing some rising and declining phases, as well as reversal points of the cycles. Among the most easily identifiable phenomena is the economic crisis of the 1930s, the post Second World war growth period, or the economic crisis started in the 1970s. However, as shown by a study of Andrew Tylecote ${ }^{2}$, the long economic cycles are less identifiable for the 1850-1930 period, unless the disruptive effects of the American civil war and of World War I are considered: their recessive then reflationary effects would have disrupted the rising and declining phases. But some analyses present the war as being a central factor in long-term economic changes. G. Modelski ${ }^{3}$ 's theory of long cycles has become very famous in the 1980s. It identifies cycles of 100-120 years, starting with an exceptionally long global war (it may also be a more discontinuous phase of war, like the two world wars), and giving rise to a new dominant power. Its technological and commercial domination permits to keep an uncontested supremacy, until some competing powers start to erode it. However, this theory does not focus on the links between major wars and long-term economic changes.

This issue having been largely studied in the past, the first part of the paper will present a review of these analyses. It will then in a second part be asked if these ideas may help predicting future major economic crises and related international conflicts. It's a delicate task, as it is as difficult to show subsequently a link between economic cycles and major wars as to predict future cyclical phenomena on the world economic and political scene.

\section{I - The various aspects of the link between economic cycles and wars}

The economic studies underline two contradictory effects of wars, reflationary and recessive. From the 1920s, the cycles' analysis presents a new type of explanation, showing a relation between the outbreak of major conflicts and certain phases of long economic cycles.

\section{I.1. War as an outcome of a long phase of economic growth}

The statistical studies of N.D. Kondratiev show long cycles of forty or sixty years, regulating the capitalist economies. The cycles and consequently the economic crises are presented as elements of the complex capitalist economic system's process. Kondratiev ${ }^{4}$ has included wars and civil unrest in his analysis: the periods of economic expansion of advanced capitalist countries create an increased demand for raw materials and new outlets for the products. This should generate new international tensions and even some wars. At the

\footnotetext{
${ }^{1}$ Kondratiev N.D. (1935), "The long waves in economic life", The Review of Economic Statistics, 17 (Nov), pp. 105-115. Cet article est une présentation synthétique des travaux conduits par l'économiste russe dans les années 1920.

${ }^{2}$ Tylecote A. (1992), "History as a forecasting tool : the future of the European economy in a long-wave/longcycle perspective", Review of Political Economy, 4.2., pp 226-248

${ }^{3}$ Modelski G. (1987), Long cycles in world politics, London, Macmillan.

${ }^{4}$ Kondratiev N.D. (1935), op.cit.
} 
domestic level, this economic growth also exacerbates the economic contradictions inherent to the capitalist system, and they therefore favour political unrest ${ }^{5}$. In Kondratiev theory, wars, revolutions and territorial annexation are some consequences rather than the causes of the long economic cycles. They generally appear at the top of a rising phase; then the wars create destructions and unproductive consumption, therefore raising the demand for capital. This analysis is therefore fundamentally Marxist, what has not prevented the Marxist orthodoxy to reject it. Though N. Kondratiev introduced his works as Marxist, he was shot in 1938 after having been sent to Gulag. His long cycle's theory indeed contradicted the Leninist dogma, based on the idea of imperialism being the highest stage of capitalism. The major imperialist war that should occur thanks to increasing commercial and colonial tensions would allow proletarian revolutions in the most advanced capitalist countries ${ }^{6}$. Kondratiev cycles' theory was judged as subversive, as it showed the capability of capitalism to overcome major economic crises.

Many studies have later followed Kondratiev line, as the one of H.T. Davis in $1941^{7}$, presented by V. Tarascio ${ }^{8}$. Davis' theory is based on the idea of fifty years' war cycles, the wars starting at the end of a long phase of commercial expansion and inflationist tensions, notably due to the increased demand for natural resources. Davis even calculates of war intensity coefficient, based on the difference between the prices' level in wartime and the average prices' level before the conflict. Contrary to Kondratiev, Davis presents a mutual interaction between war cycles and economic cycles.

\section{I.2. Wars recessive effects}

Since the origins of the liberal economic school, the cost of the war has been underlined ${ }^{9}$. One of the most popular arguments is the one of the debt burden for the country when peace returns, if the war has been financed through loan, what seems unavoidable ${ }^{10}$.

Beyond the issue of public expenditures and related debt, the liberal economists present wars as being costly and counter-productive, because of human capital losses, of material destructions, of trade disruptions or of the rise in unproductive military staff. The works of J. Stiglitz and L. Bilmes ${ }^{11}$ on the cost of the Iraq war present this conflict as a long-term economic burden for the American economy: the reflationary effect of this war would then be insignificant compared to its long-term recessive consequences.

During the 1920-1945 period, several analyses of the link between wars and long economic cycles have developed, following Kondratiev works. Their conclusions are various, notably on the sense of the causality. Indeed, these studies remain very contingent and mostly suitable for the explanation of the 1930s economic crisis. Many studies have indeed focused on the role of monetary problems in causing recessions, after a major war. Like this, in his analysis

\footnotetext{
${ }^{5}$ La théorie de Kondratiev (entre 1922 et 1928) sur la liaison entre les cycles de guerre et les cycles long est présentée de façon détaillée par Tarascio V.J. (1989), "Economic and war cycles", History of Political Economy, 21 (1), pp. 91-101.

${ }^{6}$ Lénine V.O. (1971 [1916]), L’impérialisme, stade suprême du capitalisme, Paris, Editions Sociales. Certains économistes marxistes de la période s'opposeront au déterminisme de cette analyse, expliquant notamment, comme Hilferding ou Kautsky, que le rôle de l'Etat ou les politiques d'alliances entre grandes puissances pourront empêcher la survenue de tels conflits majeurs annonciateurs de la fin du capitalisme. Ces doutes seront condamnés comme contre-révolutionnaires par les léninistes orthodoxes. (Voir Coulomb F. (2004), Economic theories of peace and war, London, New York, Routledge.)

${ }^{7}$ Davis H.T. (1941), The analysis of economic time series, Bloomington, Indiana, Principia Press.

${ }^{8}$ Tarascio V.J. (1989), op.cit.

${ }^{9}$ Voir Coulomb F. (2004), Economic theories of peace and war, London, New York, Routledge.

${ }^{10}$ Sur ce point, voir par exemple Pigou A.C. (1921), The political economy of war, London, Macmillan.

${ }^{11}$ Stiglitz J., Bilmes L. (2008), “The three trillion dollar war”, The Times, February 23.
} 
of the economic consequences of the First World War, Hansen ${ }^{12}$ explains the beginning of the declining phase of the economic cycle as being caused by the rapid succession of wartime inflation followed by peacetime deflation. Bernstein ${ }^{13}$ also considers that monetary overvaluation is an explicative factor of economic depression in peacetime.

In a longer-term perspective, J. Akerman ${ }^{14}$ has presented the economic crises as a consequence of the war economy, and asserted that the economic cycles were created by political cycles. Akerman's analyses show that the changes in prices and interest rates precisely follow the war cycles. Wars' frequency is the determining factor of the long economic waves ${ }^{15}$. Though is the short run the war may create a rise in economic activity, in the longer run, the political and economic crises are positively related.

According to F.G. Dickinson ${ }^{16}$, the First World War has created negative economic effects that may explain the interwar crisis. His statistical tests show the existence of long economic cycles and he predicts that the Second World War would have even more negative economic consequences, given the loss of flexibility of the domestic economy, following the rise in State interventionism. Other economists of this time have also underlined the problem of post-war reconstruction. According to J. Lescure ${ }^{17}$, the major wars (war of 1850/73 and the two world wars) create economic imbalance, as the demand for consumption and production goods increase with the conflict, until exceeding the supply, generating a rise in prices. The increase in production, prices and revenues due the State's use of war credit, durably disorganize the economy. When peace returns, a certain time will be necessary so that the imbalances on the various markets disappear. But a new difficulty will appear: the reconstruction create overcapacities, compared to a normal situation, as what happened in the 1920s.

All these analyses concerning the depressive economic effect of war have not been confirmed by the evolution of the world economy after 1945, which has known a phase of long growth. The reflationary effect of the reconstruction has been more important. The role of the new international monetary system and of the international organizations on the long-term economic growth may also have been important.

The economic analysis of the link between the long cycles and major wars remains indeed very contingent: according to the countries and to the periods, the long-term economic consequences of wars may differ, as well as the influence of the economic context on these wars' outbreak.

\section{I.3. War, military expenditures and crisis' end}

In a Keynesian perspective, the war, or at least the war preparedness, may be efficient as a tool of economic reflation in a time of crisis. The Classical economist T.R. Malthus had already presented the economic interest of the war: while it allows containing the problem of overpopulation thanks to the human losses, it also creates a capital destruction that allows

\footnotetext{
${ }^{12}$ Hansen A.H. (1951), Business cycles and national income, W.W. Norton \& Co, New York.

${ }^{13}$ Bernstein E.M. (1940), "War and the pattern of business cycles", Americain Economic Review, 30 (3), pp. 524-535.

${ }^{14}$ Akerman J. (1944), Structures et cycles économiques, Tome premier, Paris, Presses Universitaires de France, 1955, spécialement pp. 97-113.

${ }^{15}$ Ibid., p. 112.

${ }^{16}$ Dickinson F.G., "The economic costs of war", in George A. Steiner (ed.) (1942), Economic problems of war, New York, Wiley and Sons, Chapter 23.

${ }^{17}$ Lescure J. (1947), Principes d'économie rationnelle, Paris, Editions Domat, Montchrestien.
} 
raising the effective demand, and therefore the level of the wealth ${ }^{18}$. However Malthus considered that these positive economic effects of the war would be cancelled by the negative consequences of State intervention: in wartime the public expenditures increase, notably because of the new aid given to the poor. These supplemental public expenditures encourage the population's growth, what is harmful for the national economic growth in the long run.

These ideas are to be compared to the ones of J.M. Keynes, who besides much admired his predecessor. In 1939, Keynes suggests that governments sustain the demand through the multiplier mechanism ${ }^{19}$ : the military expenditures are presented as one of the possible tools. Making the hypothesis of a rise in military expenditures of 150 millions pounds sterling, he forecasts the creation of 300.000 jobs, as well as a rise in consumption given the subsequent rise in revenues. However, the increase in arms production is only a lesser evil, as it doesn't meet the social needs and impedes in the long run the economic development's potential. The weapons being unemployed or destroyed in case of a war, the military expenditures are unproductive expenditures that send factors of production out of the economic circuit. The war's preparedness is a provisory stimulus to the economic activity but other public expenditures would be more socially useful, with longer term economic effects, as the public works. Keynes has besides asserted in 1942 that the fact that a country was forced by the international community to give up military expenditures would permit to accelerate its economic recovery and its industrial development ${ }^{20}$. According to him, Germany should therefore be asked to participate in collective peacekeeping operations in peacetime.

The Keynesian perspective of the short or mid-term economic effects of war has been continued in the 1980s by J.K. Galbraith ${ }^{21}$, who shows the inertia effect of military expenditures. Less flexible downward than other public expenditure in a time of budgetary restrictions, they are also less flexible upward in a time of growth and overheating, the military expenditures growing less fast than other public or private expenditures. On contrary, in a time of depression, given the inertia effects of the defence sector (programs' are pluriannuelle and the personnel expenditures, little flexible, are important), these expenditures have a stabilizing effect. The defence budget would therefore be a stabilizing element of the capitalist economic systems, and notably of the American economy.

\section{II - The current relation between economic cycles and major wars}

If the debate on the link between economic cycles and major wars has been popular in the interwar period, it is less the case today, maybe given the lack of a major economic crisis comparable to the one of the 1930s or of a new world war. However the crisis of the 1970s (which end remains controversial), but also the Cold war, may be included in this debate, as well as the current Global War on Terror lead by the United States.

But the economic analyses of the economic cycles after 1945 have been dominated by the concept of innovation, following the thought of J.A. Schumpeter. And yet, the link between major innovation and militarism has only been weakly studied. Moreover, the current analyses do not pay attention to the role of wars and/or of threat of war in the long-term economic changes. The economic consequences of the Cold war, that has lasted more than 40

\footnotetext{
${ }^{18}$ Malthus T.R. (1986 [1836]), Principles of political economy, in The Works of Thomas Robert Malthus, edited by E.A. Wrigley and David Souden, London, William Pickering, vol. VI.

${ }^{19}$ Keynes, J.M. (1939), “Will Rearmament Cure Unemployment?”, The Listener, 1st June, in: D. Moggridge, ed., The Collected Writings of John Maynard Keynes, Volume 21.

${ }^{20}$ Keynes, J.M. (1942), “Inter-Departemental Committee on Reparation and Economic Security”, 21 December, in: D. Moggridge, ed., The Collected Writings of John Maynard Keynes, Volume 26.

${ }^{21}$ Galbraith J.K. (1995 [1994]), Voyage dans le temps économique, Le Seuil, Paris, p. 264 (Original title : A journey through economic time. A firsthand view, 1994).
} 
years, and the ones of the current American war on terror, may however have a long-term economic impact.

\section{II.1. The complex link between economic cycles, major innovations and defence budgets.}

After 1945, the economic analyses of long cycles have focused on the role of innovations and of the subsequent societal changes, without integrating possible military determinants. However the importance of military credits in the development of major innovations has been recalled by recent works.

\section{- The legacy of J.A. Schumpeter}

The Schumpetarian analysis is maybe the most famous explanation of the long economic cycles of capitalism. And yet, Schumpeter rejects the idea of significant externalities of militarism or war. He considers that the effect of the important increase in military expenditures before World War has been more recessive than reflationary for the economic activity $^{22}$. He moreover doesn't recognize any role to wars in long-term econmoic cycles of capitalism $^{23}$. The change in capitalism is due to the process of creative destruction, generated by the new products, new markets, new production techniques or new methods of industrial organization. These changes allow the permanent renewal of the industrial base, maintaining the capitalist economic dynamics. According to Schumpeter, the military sector and the wars cannot be considered as responsible for economic reversal, allowing the economy to emerge from a phase of depression and to benefit from growth. The wars are not presented as having a leading role in the capitalist system's changes : they may create conditions favourable for the industrial changes but at last, only the major innovations have a central role in the longterm capitalism's changes ${ }^{24}$. And yet the role of the military sector in the development of these major innovations isn't evoked. According to the economist, wars have not been decisive for the progress of capitalism. In the case of Germany for example, it's the customs union (Zollverein), more than the political unity coming from the war with France, that has favoured the economic development. The political actions, the wars, the territorial conquests and the conflicts for raw materials, have only had little impact on economic changes: only the technical progress are really determinant. And yet, while favouring the rise in interventionism and of bureaucracy, the wars make progressively disappear the spirit of capitalism and consequently the chances of major innovations development. Schumpeter therefore predicts that in the long-term, capitalism societies will be closer to the socialist model, what he regrets.

Some contemporary analyses of the long-term changes in capitalism have considered innovations as central, notably the theory of endogeneous growth. The question may be raised to know if major wars favour the development of these major innovations.

\section{* The role of military credits in the technological development}

Opposite to the Schumpeterian theory is the idea according to which the military sector may be more liable than the private sector to make major innovations appear. Among

\footnotetext{
${ }^{22}$ Schumpter J.A. (1939), Business cycles: a theoretical, historical and statistical analysis of the capitalist process, New York, London, Mc Graw-Hill Book Co. Inc.

${ }^{23}$ Schumpeter J.A. (1961 [1934]), The theory of economic development. An inquiry into profits, capital, credit, interest, and the business cycle, Cambridge, Harvard University Press.

${ }^{24}$ Schumpeter J.A. (1965 [1942]), Capitalisme, socialisme et démocratie, Paris, Editions Payot.
} 
the analysts defending this argument, the one of V.W. Ruttan ${ }^{25}$ is interesting. According to his study on the American case, the demand related to the defence sector has largely contributed to accelerate the learning process of new technologies. He more specifically studies the sectors of aeronautics, nuclear energy, computer industry, internet and space. In these sectors, the technological maturity, necessary so that the innovations generate productivity gains, would according to him have been more rapidly reached thanks to the demand of the military sector, very important notably during the two world wars and then the Cold war. As during the first half of the $19^{\text {th }}$ century, the rise in the electricity industry has been the main impetus to the rise in the global productivity for the American economy, in the last decadres of the $20^{\text {th }}$ century the computer and the microprocessors have played the same role. These technologies have had an important reflationary effect. Ruttan's thesis is that only a threat of a major war could make emerge a new technology capable of rising durably productivity rates. The private sector will never be able to have the same role, as the related gains may be too weak and too diffuse to be captured by the firm that is engaged in the research, because of the slowness of the innovation's emergence, that may take some decades.

This idea has been followed in many recent analyses on the long-term effect of the defence expenditure at the world level and of the growing privatization of military research and development ${ }^{26}$. Nowadays a large share of the production for the military sector is based on dual technologies. There is now an interaction between military and civil research.

However the rise in the American military budget at the beginning of the 2000s has given important credits for the military R\&D. The military sector being not concerned by the rules of the World Trade Organization, the public credits given to military projects may be considered as subsidies for the industry at large, and notably to the sectors of telecommunications and microtechnologies. The debate on the link between economic cycles and military expenditures therefore remains relevant today.

\section{II.2. The Cold war, the Global War on Terror and the analysis of the economic cycles}

The question of the bond between business cycle and major war can seem obsolete, if it is considered that since the end of the second world war, the probability of which has occurred of a new major war was reduced. But the Cold war can to a certain extent to be regarded as a major conflict, being given the broadth of the American and world military expenditure over the period 1948-91, with peaks related to the conflicts Korean and Vietnamese like with the revival of the arms race of the years 1980 .

Current the 'total Guerre against terrorism' American also has a width resulting from the convergence of several minor conflicts (Iraq, Afghanistan), which will be able perhaps in the long term to lead the historians to qualify it major war. The evocation of the economic consequences of these two conflicts is thus interesting for our study.

- The economic crisis begun in the years 1970 and it (future?) major war

For certain economists, the economic crisis which struck the industrialized countries with the beginning of the year 1970 is still not completed. According to this theory, defended in particular per H. Patomäki, capitalism is always in the downward phase of a long cycle and the policy of the dominant power, the United States, would prevent any inversion of tendency, owing to the fact that it prevents reforming the international institutions effectively and from

\footnotetext{
${ }^{25}$ Ruttan V.W. (2006), Is war necessary for economic growth? Military procurement and technology development, New York, Oxford University Press.

${ }^{26}$ Voir notamment Bellais R. (2004), « Le rôle croissant du secteur privé dans la recherche-développement de défense : une mutation appropriée ? », Arès , 21 (53), 37-46.
} 
revealing novel modes of economic organization. A world war could in the long term result from this world economic crisis, because of progressive aggravation of the international tensions.

Such an approach seems to us however contestable because it removes any direction with the concept of economic crisis. The United States profited during the Nineties from rates of economic growth without precedent, higher than those of the boom of the Fifties and Sixties. The other industrialized countries also obtained comfortable growth rates during the Nineties, and the level of total wellbeing of the populations increased. Several countries of the South caught up with part of the delay which separated them from the countries of North, in terms of income per capita. To consider that capitalism still did not leave the economic crisis of the Seventies thus does not seem us not justified. The idea that only a world war could reverse the tendency seems also contestable, the more so as the cold war can be regarded as having been a major and world conflict. The question of its economic impact thus deserves to be studied.

\section{- The difficult estimation of the economic influence of the Cold war}

The economic impact of long run on the capitalist economies of the cold war and the American-Soviet arms race is difficult to interpret. There is no bond between the evolution of the world military expenditure since the years 1950 and that of the economic growth. If it is admitted that the worldwide economy entered a downward phase of a long cycle at the end of the years 1960, the question of the factor release arises: exhaustion of the model fordist according to the theory of the regulation, need to open new markets and new needs for consumption for the theorists for the innovation, but that can be also interpreted like the result of the aggravation of the cold war, at the time of the war of Vietnam. However the rise in the induced military expenditure on the level of the capitalist countries does not seem sufficient to have a significant economic impact. The israélo-Palestinian conflict also played a part, as a release of the oil crisis of 1973. But this conflict was not really integrated in the cold war and cannot be regarded as a major war.

The end of the cold war on the other hand corresponded to a new phase of growth for the capitalist countries, and initially for the United States, which profited from growth rate without precedent of their GDP during the period 1992-2000, with a level of very weak unemployment. If it is admitted that world capitalism entered a phase of long growth to the beginning of the year 1990 (what is disputed by many economists), several factors in bond with the cold war can be proposed: long-term consequence of the revival of the public expenditure, mainly of the military expenditure, by the Reagan administration in the years 1980; benefit induced by fall of the military burden at the end of the cold war and the tax pressure decrease; rise of new markets related to the sector of communication and information technologies whose development was hastened by technological and military competition with the USSR. In addition, the statute of uncontested capitalist super power acquired by the United States because of their military supremacy their made it possible to obtain determining economic advantages: attraction of the overseas investments, imposition of the commercial opening to many countries, by the means of GATT and of the IMF, massive debt without important monetary depreciation, neither escape of the foreign assets, nor inflation. These positive effects of the cold war for the US economy raises the question of the real determinants of the arms race and the diplomatic confrontation with the USSR.

But another point of view on the cold war is to consider that the US economy entered an inescapable phase of decline as from the years 1970, and that its recent domination was rather a domination by defect, because of the specific problems of Japan (crisis banking) and Germany (cost of the reunification). The analyzes of Galbraith defended of the arguments supporting this assumption and largely put in charge militarism growing in the exhaustion of the American model. 
The assumption can be made that the 'total Guerre against terrorism' (Total War one Terror) started by the United States in 2001 with the invasion of Afghanistan, and continued by the war of Iraq begun in 2003, can in the long term be regarded by the historians as a major war. The American budget of defense indeed reaches levels similar to the peaks of the cold war. The bond between the economic evolutions of long run and increasing militarism in the United States can be interpreted in two ways:

- Militarism and foreign operations help maintaining the American economic power: beyond the issue of oil supply and of research-development subsidies through the military budget, it's the role of the United States as an uncontested world superpower which is at stake today: the confidence in the American supremacy has an impact on the territorial attractiveness for foreign investors and so to capital inflows necessary for the economic growth and for the dollar's stability. It's also necessary for the efficiency of the soft power, that is, the diplomatic influence, useful to play on the international rules and economic agreements.

- The other hypothesis is that the militarism and the foreign operations are elements of an unelectable decline of the American economy, which is paralysed by the military burden, which high level is due to the role of the military-industrial lobby. Several analysts, among who J. Stiglitz, have criticized the economic cost of the Global War on Terror, notably because of the long-term burden of the social expenditures and of the public debt induced. More generally, the rise in the deficits may question the national economic model, which is characterised by an easy credit and households' over-indebtedness, leading to financial crises. This creates numerous subsequent problems, as the risk of an uncontrolled inflation or of the dependency towards other countries that own a part of the public debt. And yet, the role of the military expenditures in the growing indebtedness of the United States is important.

\section{Conclusion}

The economic analysis of capitalism's cycles became popular following Kondratiev works, as it allowed explaining the succession of phases of long growth and of economic crisis since the industrialization process. It is however less easy to identify the link with the major conflicts, as the war of $1850 / 73$ or the two World Wars. The diversity of the elements to be considered so as to estimate the real economic impact of a war makes it difficult to show its long-term economic impact. Moreover, another explanation of the beginning of a rising phase of a long cycle has become dominant with time: the one of Schumpeter, who underlines the role of major innovations and who rejects the hypothesis of a link between major war and economic cycle. In the 1980s, the increased international competition with the growing trade interdependency, the financial globalization and the development of new economic powers, has definitely imposed the idea that innovation is at the heart of the capital system. The end of the Cold war and the spreading of the market economy's model seem to have removed all threat of major war to come. The issue of the link between economic cycles and major war therefore seems to belong to the history of economic thought. However, the current changes may lead to revise this idea: recent events have shown the structural tensions on raw materials' markets, due to the growing demand from emerging countries ${ }^{27}$. The destruction of industrial jobs in the richest countries favours domestic tensions, while environmental problems raise the threat of future international and civil conflicts, due to food shortage and

\footnotetext{
${ }^{27}$ Sur la question de l'aggravation probable des tensions Nord-Sud liées au commerce de biens énergétiques, voir Williams P. (2007), "Market cycles, power politics and the latest North-South energy-trade conflict", Third World Quarterly, 28 (1), pp. 45-58.
} 
subsequent migrations. Now the possibility of predation wars and of conflicts for the control of overseas resources reappears. Moreover, the hypothesis of a link between major innovation and major war or threat of war (as during the Cold war), remains relevant. Indeed, the military credits and the imperatives of the national defence have often allow to accelerate the development of innovations improving the productivity in the long-term, and so the economic growth. Now, in the future, some new major threats will accelerate the development of revolutionary technologies that would open new markets, change the techniques of production, the modes of social organization, maybe opening a new long phase of economic growth at the world level. The research linked to environmental concerns may lead to such results, and it could be increased if some major ecological disasters would create new international tensions. But the economic analysis is not able to definitively show the link between economic cycles and wars or major threats for the world peace.

\section{BIBLIOGRAPHIE}

Aglietta M. (1976), Régulation et crises du capitalisme, Paris, Calmann-Lévy.

Akerman J. (1944), Structures et cycles économiques, Tome premier, Paris, Presses Universitaires de France, 1955, spécialement pp. 97-113.

Barbieri K., Reuveny R. (2005), "Economic globalization and civil war", The Journal of Politics, 67 (4), November, pp.1228-1247.

Barrère A. (1947), Les crises de reconversion et la politique économique d'après-guerre, Paris, Librairie Marcel Rivière.

Bellais R. (2004), "Le rôle croissant du secteur privé dans la recherche-développement de défense : une mutation appropriée ? ", Arès , 21 (53), 37-46.

Bernstein E.M. (1940), "War and the pattern of business cycles", Americain Economic Review, 30 (3), pp. 524-535.

Bosserelle E. (1993), "Les cycles longs du capitalisme: un point de vue sur soixante dix ans de débats", Les Cahiers de l'Association Charles Gide pour l'Etude de la Pensée Economique, Vol. 5, pp. 31-54.

Boyer R. (1986), Théorie de la régulation, une analyse critique, Paris, La Découverte.

Boyer R., Didier M. (1998), Innovation et croissance, Rapport du CAE, Paris, La Documentation Française

Cohen E., Lorenzi J.H. (2000), Politiques industrielles pour l'Europe, Rapport du CAE, Paris, La Documentation Française.

Coulomb F. (1998), “Adam Smith, a defence economist”, Defence and Peace Economics, 9 (3), pp. 299-316.

Coulomb F. (2004), Economic theories of peace and war, London, New York, Routledge.

Coulomb F. \& Fontanel J. (2005), «An economic interpretation of French military expenditures », Defence and Peace Economics, 16 (4), 297-315.

Davis H.T. (1941), The analysis of economic time series, Bloomington, Indiana, Principia Press.

Dickinson F.G., "The economic costs of war", in George A. Steiner (ed.) (1942), Economic problems of war, New York, Wiley and Sons, Chapter 23.

Fukuyama F. (1992), The end of history and the last man, New York, Free Press.

Galbraith J.K. (1995 [1994]), Voyage dans le temps économique, Le Seuil, Paris, p. 264

(Original title : A journey through economic time. A firsthand view, 1994). 
Grand-Jean P. (1964), Guerres, fluctuations et croissance, Prix de thèse de la faculté de droit et des sciences économiques de Caen, Paris, Sedes, pp. 386-399.

Hansen A.H. (1951), Business cycles and national income, W.W. Norton \& Co, New York.

Keynes, J.M. (1939), "Will Rearmament Cure Unemployment?", The Listener, 1st June, in: D. Moggridge, ed., The Collected Writings of John Maynard Keynes, Volume 21.

Keynes, J.M. (1942), "Inter-Departemental Committee on Reparation and Economic Security", 21 December, in: D. Moggridge, ed., The Collected Writings of John Maynard Keynes, Volume 26.

Kondratiev N.D. (1935), "The long waves in economic life", The Review of Economic Statistics, 17 (Nov), pp. 105-115.

Lénine V.O. (1971 [1916]), L'impérialisme, stade suprême du capitalisme, Paris, Editions Sociales.

Lescure J. (1947), Principes d'économie rationnelle, Paris, Editions Domat, Montchrestien.

Malthus T.R. (1986 [1836]), Principles of political economy, in The Works of Thomas Robert Malthus, edited by E.A. Wrigley and David Souden, London, William Pickering, vol. VI.

Modelski G. (1987), Long cycles in world politics, London, Macmillan.

Oneal J.R., Russett B.M. (1997), "The Classical liberals were right: democracy, interdependence and conflict", 1950-1985, International Studies Quarterly, 41, pp. 267-294.

Patomäki H. (2005), "The long downward wave of the world economy and the future of global conflict", Globalizations, 2 (1), 61-78.

Pigou A.C. (1921), The political economy of war, London, Macmillan.

Ruttan V.W. (2006), Is war necessary for economic growth? Military procurement and technology development, New York, Oxford University Press.

Schumpeter J.A. (1961 [1934]), The theory of economic development. An inquiry into profits, capital, credit, interest, and the business cycle, Cambridge, Harvard University Press.

Schumpter J.A. (1939), Business cycles: a theoretical, historical and statistical analysis of the capitalist process, New York, London, Mc Graw-Hill Book Co. Inc.

Schumpeter J.A. (1965 [1942]), Capitalisme, socialisme et démocratie, Paris, Editions Payot.

Stiglitz J., Bilmes L. (2008), "The three trillion dollar war", The Times, February 23.

Tarascio V.J. (1989), "Economic and war cycles", History of Political Economy, 21 (1), pp. 91-101.

Tylecote A. (1992), "History as a forecasting tool : the future of the European economy in a long-wave/long-cycle perspective", Review of Political Economy, 4.2., pp 226-248

Williams P. (2007), "Market cycles, power politics and the latest North-South energy-trade conflict”, Third World Quarterly, 28 (1), pp. 45-58. 